Food storage materials of seed of the two pines are composed chiefly of fatty oil $(55.5$ per cent in sugar pine seed and 50 per cent in Jeffrey pine seed), proteins and sugars. It is seen that more than one half of the reserve food material in seeds of both pines consists of oil, and that sugar pine has more of it than Jeffrey pine. Analyses have shown that the oil of sugar pine seed has an iodine value of 150.5 while the oil of Jeffrey pine seed has an iodine value of $136 \cdot 4$. There is thus a higher degree of unsaturation in the seed oil of sugar pine.

In ordinary storage the most unsaturated component of the pine seed oil-linolenic acid-disappears gradually in all seeds but more rapidly in sugar pine than in Jeffrey pine seed. In the seeds of both species stored at $5^{\circ} \mathrm{C}$., on the contrary, no appreciable losses in linolenic acid were detected. When sugar pine seeds were chilled in moist sand for three months, only traces of linolenic acid were found at the end of that period. Prolonged storage at ordinary temperatures results in decrease of germination capacity of sugar pine seed, whereas chilling in moist sand results in an increase; yet in both cases linolenic acid disappears.

Although a possible role of unsaturated fatty acids and especially of linolenic acid in germination and longevity of oleaginous seed has received very little attention, its importance in biological oxidation has been emphasized by Meyerhof ${ }^{1}$. This author discussed at length Warburg's findings that "of all the unsaturated acids, linolenic acid alone with its three double linkages shows autoxidation with iron". During autoxidation the number of double bonds decreases and the reaction proceeds as follows :

$$
\begin{aligned}
& \mathrm{CH}_{3} \cdot \mathrm{CH}_{2} \cdot \mathrm{CH}=\mathrm{CH} \cdot \mathrm{CH}_{2} \cdot \mathrm{CH}=\mathrm{CH} \cdot \mathrm{CH}_{2} \cdot \mathrm{CH}=
\end{aligned}
$$

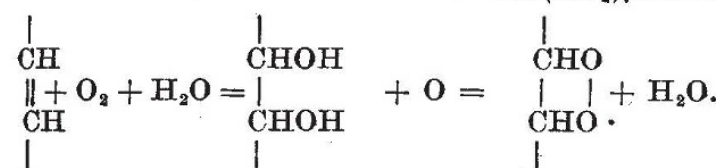

Meyerhof distinguishes between the reaction in vitro where it stops on the conversion of linolenic acid into slightly oxidized products, and a reaction in vivo where it progresses as far as formation of carbon dioxide.

In stored seed where life processes are hindered, conditions perhaps are similar to those existing in vitro. Slightly oxidized produets are formed and these are gradually polymerized into inactive substances. The degradation of the unsaturated acids, and especially of the linolenic acid, proceeds faster in sugar pine seed than in Jeffrey pine seed. During the incipient period of germination of sugar pine seed the conditions may be similar to a reaction in vivo. Here disappearance of linolenic acid is probably connected with respiration and also with transformation of fats into carbohydrates.

The final results in both cases are precisely the same, namely, disappearance of linolenic acid, but the course of oxidation is quite different. In one instance it possibly causes death of the seed, while in the other it probably represents the first stage of germination connected with the utilization of stored food materials.

Of course, variations in linolenic acid contents in the seed of the two pines do not explain yet why Jeffrey pine seed germinates well under ordinary conditions and sugar pine seed does not. The experi- ments show that it might be connected with differences in the status of growth hormone in the seeds of the two species, but the discussion of this phase of germination is beyond the scope of this paper.

"Meyerhof, Otto, "Chemical Dynamics of Life Phaenomena" (Philadelphia and London, J. B. Lippincott Co., 1924).

\section{ASSOCIATION OF UNIVERSITY PROFESSORS AND LECTURERS OF THE ALLIED COUNTRIES IN GREAT BRITAIN}

\section{ANNUAL MEETING}

$\mathrm{T}$

HE fifth general meeting of the Association of University Professors and Lecturers of the Allied Countries in Great Britain was held in Cambridge during June 24 and 25,1944 . It was the annual meeting, a sequel to the annual meeting of 1943 held in Oxford, and a special significance was attached to it as a friendly gathering, as well as a business meeting, in view of the not unreasonable expectation that the members may have separated to their own countries before the next annual meeting falls due.

The morning of June 24 opened with meetings of Section IV (Student Affairs), chairman, Prof. R. D. Laurie (Great Britain); Section VIII (Modern Humanities), chairman, Prof. L. E. Genissieux (France); and Section IX (History), chairman, Dr. de Sturler (Belgium). Then all Sections met for a lecture on the history of the Cavendish Laboratory by Sir Lawrence Bragg. The afternoon followed the same pattern : meetings of Section II (Collaboration with International Bodies), chairman, Prof. J. Timmermans (Belgium); Section V (Law), chairman, Prof. B. Helczynski (Poland); Section VI (Science and Technology), chairman, Prof. A. Photiades (Greece); and Section VII (Economy), chairman, Prof. J. A. Veraart (Netherlands), and after tea in the gallery of Emmanuel College a lecture by Prof. G. M. Trevelyan on the history of the University of Cambridge.

On June 25 the General Assembly met, and was welcomed by the vice-chancellor, Dr. T. S. Hele, master of Emmanuel College.

The president of the Association, Prof. J. Timmermans, then gave his address, which was a résumé of the year's work and progress. He pointed out that it has been a period of consolidation but that also there have been new departures. The Executive Committee had found sufficient work to require a meeting each month, with two in May. An Education Conference was held in April on lines similar to that held in the spring of 1943, and the British Council again guaranteed a very considerable contribution towards defraying the cost of publishing the report. The Publicity Committee, under the chairmanship of Prof. Photiades, carried through the publication of Communication, addressed to members, of which three numbers have already appeared and of which some half-dozen are planned to be produced during twelve months. Prof. Timmermans reviewed the activities of members of the Executive Committee in relation to other organizations having similar interests, notably the Conference of Allied Ministers of Education, the London International Assembly, the British Association Committee on Post-War 
University Education and the International Relations Committee of the Association of University Teachers. One of the most conspicuous developments of interest to the Association during the year was the events following the visit of the American education delegation. This delegation co-operated with the Conference of Allied Ministers of Education in producing a scheme for a United Nations Organisation for Educational and Cultural Reconstruction, which is now under consideration by the United Nations Governments. It is the hope of the Association that it will be able to establish useful contacts with this important Organisation.

Dr. Grayson N. Kefauver, who represents the United States Government in connexion with the development of the United Nations, Organisation for Educational and Cultural Reconstruction, was present, and addressed the meeting. He explained the attitude of the United States and the purpose of the new Organization, and welcomed the suggestion of co-operation from the Association of Allied University Professors.

The reports of the various sections were then received by the Assembly, indicating that a considerable amount of work is in hand on a variety of topics. Arising therefrom it was resolved on the recommendation of Section IV that the Memorandum on Student Health which was printed in No. 1 of Communication be adopted.

The afternoon session was devoted to a discussion on the draft statutes of the proposed International Association. The importance of a thorough discussion was recognized by all, and it was felt undesirable to proceed to final decisions at this meeting as this was the first occasion on which the General Assembly had had an opportunity of expressing its views. The Executive Committee was asked to undertake some redrafting in the light of the discussion, for presentation to the next general meeting.

Prof. J. A. Veraart (Netherlands) was elected president for the session 1944-45. Other members of the Executive Committee were elected as follows : Belgium; Prof. J. Timmermans; Czechoslovakia, Prof. V. Klecanda ; France, Prof. P. Vaucher; Great Britain, Prof. R. D. Laurie; Greece, Prof. A. Photiades; Netherlands, Prof. J. A. Veraart; Norway, Prof. A. Sommerfelt; Poland, Prof. B. Helczynski ; U.S.A., Prof. A. L. Goodhart; Yugoslavia, Prof. S. Yovanovic.

\section{APPOINTMENTS VACANT}

APPLIOATIONs are invited for the following appointments on or before the dates mentioned:

ILOTURER (temporary) IN PHYsIoLOGY-The Registrar, King's College, Newcastle-upon-Tyne 2 (August 16).

A8sistant MASTER to teach ScIENCE SUBJicts to Junior Technical Classes and to Apprentice Day Classes in the Mill Street School of Building, Manchester-The Director of Education, Edueation Offices, Deansgate, Manchester 3 (August 16).

SENIOR TECHNICAL OFFICER on the staff of the Northamptonshire Institute of Agriculture, Moulton, Northampton-The Secretary for Education, County Education Offices, Northampton (August 18). Assista County Education Ofhces, Northampton (August 18. sity, Leeds 2 (August 19).

AssistaNT LEOTURER IN BOTANY-The Registrar, The University, Manchester 13 (August 19).

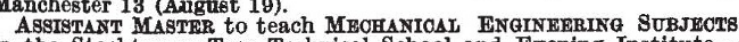
in the Stockton-on-Tees Technical School and Evening InstituteThe Director of Education, Shire Hall, Durham (August 19).

SPEECH THERAPIST-The Director of Education, Town Hall, SPEECH THERAPIST-The Director
nkeston, Derbyshire (August 19).

AGRICULTURAL ChEMIST-The Principal, Agricultural Institute and AgRICULTURAL Chemist-The Principal, Agricultural Inst
Experimental Station, Kirton, Boston, Lincs. (August 19). Assistant Psychorogrst-The Chief Education Officer, 2 Cecil Aoad, Bristol 8 (August 21). LBCTURRR (temporary) IN PHYsIos-The Registrar, University College, Southampton (August 21).
ResearoH MANAGER to an Engineering Company in the Midlands (must possess an Honours Degree in either Engineering or Physics)The Ministry of Labour and National Service, Room 432, Alexandra House, Kin

Cryit Work in India and Burma-The Ministry of Labour and National Service, India and Burma-ine House, Kingsway, London, W.C.2 (quoting Reference No. E.1069. XA) (August 21)

(quoting Reference No. The School Medical Offlcer, County Hall, Chichester (August 23).

SENIOR POST under the Aeronautical Inspection Directorate (must possess a Degree in Metallurgy or recognized equivalent)-The Ministry of Labour and National Service, Room 432, Alexandra House, Kingsway,

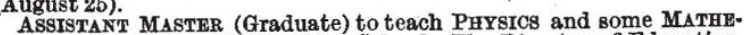
ASSISTANT MASTER (Graduate) to teach PHYSICs and some MATHE-
MATIOS in the Sheffield Technical School-The Director of Education, Matios in the Sheffield Technical School-The Director of

Education Offlce, Leopold Street, Sheffield 1 (August 26).
READERSHIP IN PHYSICAI ANTHROPOLOGY-The Registrar, UniverREADERSHIP IN PHYSICAL ANTHRO
sity Registry, Oxford (August 31).

SECRETARY to the Editorial Board of the 'Transactions' (must hold a Degree in Physics, Metallurgy or Engineering of a British University, or an equivalent technical qualification)-The Secretary,
Institute of Welding, 2 Buckingham Palace Gardens, London, S.W.1

Institute of

CHIEF Electrical Engineme aND Manager-The Town Clerk, Town Hall, Chichester (August 31).

BOROdGH EIECTRICAL ENGINEER AND MANAGRR-The Town Clerk,

4 Woodville Terrace, Gravesend, Kent (September 1).

UNIVERSITY CHAIR OF STATISTICS tenable at the London School of Economics-The Academic Registrar, University of London, South Kensington, London, S.W.7 (September 4).

CURATOR OF THE CrTY MUSEUMS-The Town Clerk, Room 57, Civic Hall, Leeds 1 (endorsed 'Curator of the City Museums') (September 9). CHAIR OF ELJCTRICAL ENGINEERING-The Acting Registrar, The University, Leeds 2 (September 30).

CHAIr or Brofogy in Victoria University College, Wellington, New Zealand-The Secretary, Universities Bureau of the British Empire c/o University College, Gower Street, London, W.C.1 (September 30) LIBRARIAN-The Librarian, Queen's University, Belfast (October 31). CHAIR OF PSYCHOLOGY in the University of Sydney-The Secretary, Universities Bureau of the British Fmpire, $/ 9$ University College, Gower Street, London, W.C.1 (October 31).

AssISTANT LECTURER (temporary) IN MATHEMaTIos-The Registrar, The University, Sheffield.

ASSISTANT MASTER (Graduate) qualifted to teach ENGINEERING SUBJECTS and Mathematros-The Principal, Technical Institute Beckenham Road, Beckenham, Kent.

TEACHER OF ENAINFERING SUBJEOTS (must possess a Degree or equivalent qualiflcation), and a TEACHER (man or woman) of ScrancE (with good qualiflcations in General Science or in Blology)The. Principal, Technical Institute, Darnley Road, Gravesend, Kent. ENTOMOLOGICAL FIELD OFFICER by the Government of AdenThe Ministry of Labour and National Service, Appointments Department, Sardinia

O. O.S.214). Technical School for Boys-The Principal, Wimbledon Technical College, Gladstone Road, London, S.W.19.

\section{REPORTS and other PUBLICATIONS (not included in the monthly Books Supplement)}

Great Britain and Ireląnd

National Institute of Economic and Social Research. Annual Report, 1943. Pp. 20. (London: National Institute of Economic Report, 1943. Pp. 20. (London: National Institute of Economic
and Social Research.) andish Colliery Owners Research Association and British Coal Utilization Research Association. Report of Discussions on Determination of Particle Size in Sub-Sieve Range. Pp. 69. (London: mination of Particle Size in Sub-Sieve Range. Pp. 69. Coal Utiliza: British Colliery Ownérs Research Association, and British Coal Utiliza:-
[197 tion Resesrch Association.) Institute of Physics. Report of Institute of Physics and Mathe-
matical Association on the Teaching of Mathematics to Physicists. matical Association on the Teaching of Mathematics to Physicists.
(London: Institute of Physics.) (London: Institute of Physics.) The Journal of the Institute of Metals. Vol. 69, 1943. Edited by
N. B. Vaughan. Pp. xxxvi +526 +41 plates. (London: Institute of N. B. Vaughan. Pp. $\times x x v i+526+41$ plates. (London: Institute of
Metals.)

\section{Other Countries}

Commonwealth of Australia : Council for Scientiflc and Industrial Research. Bulletin No. 174: Recent Advances in the Prevention and Treatment of Blowfly Strike in Sheep. Supplement to Report No. 2. By the Joint Blowfiy Committee. Pp. 20. (Melbourne : Government Printer.)

Smithsonian Institution, War Background Studies, No. 18 : Peoples of India: By William H. Gilbert, Jr. (Publication 3767.) Pp. ivt $86+21$ plates. (Washington, D.C.: Smithsonian Institution.) [247 Annals of the Carnegie Museum. Vol. 30, Art. 4: Affinities of Phoebis rorata Comstockd, a new Plerid Butterfly from Jamaica. By A. Avinoff. Pp. 45-56+3 plates. (Pittsburgh, Pa.: Carnegie
Museum.)
[257

\section{Catalogue}

List of German Publications being reproduced in America by the Photo-Offset Process under authorization of the Alien Property Custodian in Washington. Pp. 12. (London: H. K. Lewis and Co., Ltd.) 